\title{
The Response of Micro, Small and Medium Enterprises in the Face of the Corona Virus Diseases (COVID-19) Pandemic Situation
}

\author{
Fandi Prasetya \\ Accounting Study Program, Faculty of Economics and Business, Airlangga University, Banyuwangi Campus, \\ Banyuwangi, Indonesia \\ Corresponding author email: fandi.prasetya@feb.unair.ac.id
}

\begin{abstract}
Several business actors run the economy of a country. MSMEs are a place for people to be productive through labour-intensive businesses. However, currently, MSMEs players and several other business actors face tough challenges because they meet the COVID-19 pandemic. This pandemic has a terrible impact on human life, including the effects on the economy of a country. Therefore, with this research, we can see how business actors respond to facing COVID-19 and what assistance is needed by business actors in the current pandemic situation. This research conducted using qualitative research methods. Data collection uses literature studies. The type of data used is the Covid-19 Survey Result Data on Business Actors in Indonesia issued by the Central Statistics Agency and other documents or literature related to the research theme. Data sourced from several kinds of literature were collected then analyzed by understanding how the author's interpretation describes the response of MSMEs in the face of the COVID-19 situation. Results showed that most business actors did not reduce their employees, and they needed government assistance in terms of capital and electricity bill relief.
\end{abstract}

Keywords: Pandemic, Covid-19

\section{INTRODUCTION}

MSMEs are an essential part of a country's economy. MSMEs can reduce the unemployment rate in a country because they provide opportunities to create jobs [1] and as a means to distribute the results of development [2]. Activities carried out by MSMEs are expected to be a place for the community to be productive through labour-intensive businesses. Not a few MSMEs in carrying out their activities experience challenges to develop their businesses, and only a small portion of MSMEs have managed to grow on a larger scale [3]. The form of challenges MSMEs face wishing to increase their business scale requires several fundamental transformations in their organization and considerable capital development [4]. MSMEs need several resources, which are essential capital in their business. Therefore, a resource-based view needs to be used[5]. This is in line with the research results conducted by Andersen \& Joachim (2016), which states that resources influence the company's growth rate. A study conducted by Deligianni \& Voudouris (2011) and Mallon et al. (2018) in its research explains that specific strategies can influence and interact with company resources in overcoming an uncertain situation or environment.

MSMEs that only have particular resources do not guarantee their growth [9]. A strategy is needed to identify the resources owned, identifying the capabilities and potential to benefit from the resources owned [10]. Informal MSMEs such as street vendors are a sector that requires attention in conditions of economic uncertainty during COVID19. COVID-19 is a disease epidemic that affects human health and causes financial and economic emergencies in areas affected by the pandemic [11]. On August 5, 2020, the Indonesian Central Bureau of Statistics informed that Indonesia's economic growth in the second quarter of 2020 decreased by $5.32 \%$, this decline greatly impacted MSME business lines, especially the accommodation, food, and beverage sector [12]. The decline in people's purchasing power to buy certain goods also affects MSMEs The decline in purchasing power occurs because consumers change their consumption behavior.

The COVID-19 pandemic impact was increasingly felt for MSMEs when several Indonesian regions implemented Large-Scale Social Restrictions (PSBB). PSBB is a measure to limit activities for a particular province or regency or city in Indonesia [13]. The implementation of the PSBB has had a broad impact on several sectors, including the government, business, and household sectors [14]. At least $39.9 \%$ of MSMEs decided to reduce the stock of goods during the PSBB, while $16.1 \%$ of MSMEs chose to reduce 
employees [15]. The COVID-19 pandemic is still happening, and we do not know how long the COVID-19 pandemic will end. Therefore, this motivates researchers to find out what MSMEs will do in the face of an uncertain situation such as the Corona Virus Disease (COVID-19) pandemic. With this research, can contribute to MSME players and the government in determining what steps are right to reduce COVID-19 and improve the economy.

\section{LITERATURE REVIEW}

\subsection{Resource-Based View (RBV)}

How an organization can achieve a sustainable competitive advantage [16]. Each organizational unit has several resources that are characteristic of the organization. This allows one to maintain its competitive advantage [17]. RBV considers that an organization is a collection of resources [18]. Resources owned by the company must have 'VRIN' criteria to provide a competitive advantage and sustainable performance. VRIN consists of several measures, including the following [16].

- Valuable (V): a resource can be useful if these resources can help companies take advantage of market opportunities or reduce market threats.

- Rare (R): The company's resources are challenging to find among the company's competitors. The company must have the uniqueness that differentiates it from other companies

- Imperfect Imitability (I): resources can be the basis for a sustainable competitive advantage if it has difficulty obtaining these resources.

- Non-Substitutability $(\mathrm{N})$ : in this case, the resource cannot be replaced with other alternative resources

Resources can be classified into three categories, namely [18]

- Physical capital resources (technology, fixed assets, equipment)

- Human resources (training, experience, and insight)

- Organizational resources (formal structure)

2.2. Micro, Small, and Medium Enterprises (UMKM).

Based on the Law of the Republic of Indonesia Number 20 of 2008, it explains that:

- Micro Business

Microbusiness is a productive business that stands alone, owned by individuals and individual business entities that meet the criteria as follows a) The owned business has a maximum net worth of Rp.50,000,000 (fifty million rupiahs); however, this asset does not include land and the environment where the company located;

b) Annual sales proceed from the business; it reaches a maximum of Rp.300,000,000 (three hundred million rupiahs).

- Small Business

Small Business is a form of business that is carried out independently by individuals or business entities and becomes part of the productive economy. This small business has no relationship with medium or large businesses. The criteria of small businesses as listed are as follows:

a) Have a net worth of more than Rp. 50,000,000 (fifty million rupiah) to Rp. 500,000,000 (five hundred million rupiahs), excluding land and buildings for business premises.

b) b) The resulting annual sales proceeds reach Rp. 300,000,000 (three hundred million rupiahs) to Rp. 2,500,000,000 (two billion and five hundred million rupiahs)

- Medium Enterprises

Medium Enterprises are those that are carried out by individuals or business entities and are part of a productive economic enterprise which has the following characteristics:

$\checkmark \quad$ Has a net worth of Rp. 500,000,000 (five hundred million rupiahs) to Rp. 10,000,000,000 (ten billion rupiahs), excluding land and buildings for business premises; or

$\checkmark \quad$ The resulting annual sales proceeds reach Rp. 2,500,000,000 (two billion five hundred million rupiahs) to Rp. 50,000,000,000 (fifty billion rupiah).MSMEs, when classified based on a business perspective, can be grouped into four groups, namely [2]

a) The product quality is still not up to standard.;

b) Limited product design Because the majority of MSMEs only work according to orders, so they do not dare to innovate;

c) The types of products are still limited;

d) Capacity and product prices are still limited;

e) Raw materials that do not meet standards. Because the raw materials obtained are obtained from different sources.

f) Product continuity is not guaranteed and imperfect

\section{RESEARCH METHODOLOGY}

This article uses qualitative research methods. Data collection uses a literature study. The type of data used is the Covid-19 Survey Result Data Against 
Business Actors in Indonesia issued by the Central Statistics Agency and other documents or literature that have a relationship with the research theme. The methodology used by BPS in the Covid-19 Survey Results of Business Actors in Indonesia involved 34,559 respondents. The implementation time was 10-26 July 2020. The coverage was all business fields except the government, household activities of entrepreneurs, and international institutions. The data collection method used was by using Computer Assisted Web and Self Interviewing (CASWI) or online surveys. The sample selection method uses probability sampling by selecting 24 thousand samples from the 2020 Statistics Business Register (SBR) frame. Besides, BPS also uses NonProbability Sampling (Voluntary Sampling) by sending survey links to a network of associations, associations, associations, associations, and so on others in the form of a business actor association. Data sourced from some of the collected literature is then analyzed by understanding how the author's interpretation describes the response of MSMEs in the face of the Covid -19 Pandemic situation.

\section{DISCUSSION}

The majority of respondents to the Covid-19 survey of Business Actors in Indonesia were from the processing industry, totaling 5,522. Complete data regarding each type of business can see in table 1 .

TABLE 1. Respondent to the Covid-19 survey of Business Actors in Indonesia

\begin{tabular}{|l|l|l|}
\hline Number & Types of Business & Amount \\
\hline 1 & Processing Industry & 5.522 \\
\hline 2 & Vehicle Trade and Repair & 4.967 \\
\hline 3 & $\begin{array}{l}\text { Accommodation and } \\
\text { Food Beverages }\end{array}$ & 4.396 \\
\hline 4 & $\begin{array}{l}\text { Agriculture and Animal } \\
\text { Husbandry }\end{array}$ & 2.482 \\
\hline 5 & Other Service & 2.418 \\
\hline 6 & Company Services & 2.360 \\
\hline 7 & Finance Services & 1.687 \\
\hline 8 & Education Services & 1.634 \\
\hline 9 & Transport and Trade & 1.595 \\
\hline 10 & Construction & 1.458 \\
\hline 11 & Health Service & 1.390 \\
\hline 12 & Mining And Excavation & 1.345 \\
\hline 13 & $\begin{array}{l}\text { Water and Waste } \\
\text { Management }\end{array}$ & 1.075 \\
\hline 14 & Real Estat & 891 \\
\hline 15 & Electricity and Gas & 706 \\
\hline
\end{tabular}

\begin{tabular}{|l|lr|l|}
\hline 16 & $\begin{array}{l}\text { Information } \\
\text { Communication }\end{array}$ & and & 636 \\
\hline
\end{tabular}

As for the area's distribution, the number of respondents in Sumatra Province reached 9,302 respondents, Java Province 16,391 respondents, Bali and Nusa Tenggara reached 2,105, Kalimantan reached 2,197, Sulawesi reached 3,689, and Papua and Maluku reached 875 respondents. Covid-19 made several regions start to implement Large-Scale Social Restrictions to control the transmission of Covid-19 in Indonesia [19].

PSBB is a limitation of specific activities for residents in an area suspected of being infected with Corona Virus Disease 2019 (Covid-19). T The PSBB aims to prevent the possibility of the spread of Covid-19 Regions that meet the requirements for PSBB implementation must meet the following criteria:

a) The number of cases and or the number of deaths due to the disease is increasing and spreading significantly and rapidly to several regions

b) There is an epidemiological link with similar incidents in other regions or countries.

Activities that are limited by the existence of PSBB include at least school and workplace holidays, restrictions on religious activities, restrictions on activities in public places or facilities.

PSBB is one of the health protocols that aim to suppress the spread of Covid-19, but on the other hand, PSBB has an impact on the economy. The implementation of the PSBB in several areas will have an impact on the company's operations. The impact of COVID-19 based on the results of a survey conducted by the Indonesian Central Statistics Agency in 2020 is as follows:

a) The Company Is Still Operating As Usual $(58.95 \%)$,

b) The company operates with a reduction in the capacity of working hours, machines, and labour $(24.31 \%)$,

c) The company stopped operating $8.76 \%$,

d) The company implements Work From Home for some employees $(5.45 \%)$,

e) The company implements Work From Home for All Employees $(2.05 \%)$

f) operates $(0.49 \%)$,

So, in general, 6 out of every ten companies are still operating as normal.

Companies operating as usual in a pandemic situation like this have reduced working hours by $24.59 \%$. Companies operating over capacity before Covid increased their working hours by $24.85 \%$, while companies operating by implementing Work From Home took steps to lay off their workforce or 
around $14.04 \%$. For the company's operational conditions and the workforce's policies, $76.26 \%$ of the workforce was still permanent, $21.10 \%$ of the workforce decreased, and $2.64 \%$ increased. Termination of Employment Relations is the company's last step towards its workforce in dealing with Covid-19. Based on the results of the BPS survey, reducing work hours was the most frequent step taken by companies or by $32.66 \%, 17.06 \%$ of companies took steps to lay off and not pay their labour, $12.83 \%$ of companies laid-off workers in a short time, $6,46 \%$ of the workforce was dismissed with partial pay, and $3.69 \%$ of the workforce was dismissed with full pay.

Covid-19 made the income received by business actors decreased by $82.85 \%$, and the remaining 14.06 income received remained, and $2.55 \%$ increased. The most affected sectors were the accommodation, food, and beverage sector at $92.47 \%, 90.90 \%$ for other services, and $90.34 \%$ for the transportation and warehousing sectors - the impact of implementing the PSBB in several regions. With the implementation of PSBB, several activities are not allowed, which impacts economic activities in areas that implement PSBB. This is in line with research conducted by [20] in his research states that social distancing activities will have an impact on several community activities. In addition, several sectors also require a production chain that cannot be postponed, and if this PSBB is implemented, it will have an impact on the cessation of the production chain [21]. The same research results were produced by [22], who concluded that the implementation of the PSBB had an impact on travel service business actors. Research conducted by [23] social restrictions can cause an economic downturn.

The provinces of Yogyakarta, Jakarta, Banten, and Bali are provinces whose business actors have experienced decreasing income. The majority of the business sectors that are developing in these four provinces are the tourism sector. Based on data compiled from the Ministry of Tourism and Creative Economic website, there has been a decrease in Indonesia's foreign tourist visits. In August 2020 only totaled 164,970 visits compared to August 2019 in 2019 , which reached $1,530,268$ visits. With the decline in the tourism sector, several business actors such as accommodation, transportation, and other services experienced a decrease in income due to falling demand due to customers/clinicians affected by Covid. $87 \%$ experienced by accommodation and food and beverages providers, $85 \%$ transportation and warehousing, and $85 \%$ other services. To reduce the impact of a pandemic on business activities carried out by entrepreneurs, 15 out of every 100 companies tend to diversify their businesses during the pandemic. The processing industry is the industry that has the most diversification in the business sector, up to $21.97 \%$. There is $19.88 \%$ from the accommodation, food, and beverage business sectors, and $16.71 \%$ from the trade and vehicle repair sectors. Besides, the need to implement health protocols in the work environment in the form of physical distancing that reaches $81.91 \%$, provides handwashing facilities for $81.87 \%$, and the mandatory use of masks or face shields $85.88 \%$. The use of the internet and information technology is a way for business actors to maintain their business and increase income. $47.75 \%$ of business actors from before the Covid-19 to now have used the internet and information technology for online marketing, $5.76 \%$ of business actors just started at Covid-19. In comparison, $46.5 \%$ of business actors still have not used the internet and information technology.

\section{CONCLUSION}

Covid-19 has had a significant impact on the economy, especially business actors. The majority of them experience a decrease in income from the business sector they work in. Around $82.29 \%$ of UMB and $84.20 \%$ of MSEs experienced a decrease in income. The decrease in the income they get will impact human resources to carry out their business operations. The majority, based on the results of a survey conducted by BPS, $62.29 \%$ of companies tended to choose not to reduce or increase the number of employees working. In conditions full of uncertainty like this, MSEs and UMB players need assistance, the results of a survey conducted by BPS, assistance needed by MSEs, $69.02 \%$ of MSEs require business capital assistance, $41.18 \%$ of MSEs require a reduction in electricity bills for business, $29.98 \%$ need relaxation/delay in loan repayments, $17.21 \%$ need administrative assistance for loan applications, $15.07 \%$ require tax payment delays. For UMB, $43.53 \%$ of UMB players need electricity bill relief for businesses, $40.32 \%$ need relaxation/delay in loan payments, $39.61 \%$ need tax payment delays, $35.07 \%$ need business capital assistance, and 14, 44\% require easy administration for loan applications. Therefore, in this case, the government needs to help business actors keep operating, so it is hoped that the economy will not stop and reduce unemployment. 


\section{REFERENCES}

[1] L. Al-Haddad, M. S. Sial, I. Ali, R. Alam, N. V. Khuong, and T. H. T. Khanh, "The role of small and medium enterprises (SMEs) in employment generation and economic growth: A study of marble industry in emerging economy," Int. J. Financ. Res., vol. 10, no. 6, pp. 174-187, 2019, doi: 10.5430/ijfr.v10n6p174.

[2] Bank Indonesia, "Profil Bisnis Usaha, Mikro, Kecil, dan Menengah (UMKM)," 2015 .

[3] H. Aldrich, "Even dwarfs started small: Liabilities of size and age and their strategic implications.," Auster, Ellern R, vol. 8, pp. 165-198, 1986.

[4] L. Cassia and T. Minola, "Hyper-growth of SMEs: Toward a reconciliation of entrepreneurial orientation and strategic resources," Int. J. Entrep. Behav. Res., vol. 18, no. 2, pp. 179-197, 2012, doi: $10.1108 / 13552551211204210$.

[5] B. S. Anderson and Y. Eshima, "The influence of firm age and intangible resources on the relationship between entrepreneurial orientation and firm growth among Japanese SMEs," J. Bus. Ventur., vol. 28, no. 3, pp. 413-429, 2013, doi: 10.1016/j.jbusvent.2011.10.001.

[6] J. Andersen and S. Joachim, "1 Resource organization and firm performance - How entrepreneurial orientation and management accounting influence the profitability of growing and non-growing SMEs," Int. J. Entrep. Behav. Res., pp. 466-468, 2016.

[7] I. Deligianni and I. Voudouris, "New venture strategies and performance in a catching-up economy: Identifying a strategic typology and trajectory through case studies," Manag. Res. Rev., vol. 34, no. 7, pp. 732-753, 2011, doi: 10.1108/01409171111146652.

[8] M. R. Mallon, S. E. Lanivich, and R. L. Klinger, "Resource configurations for new family venture growth," Int. J. Entrep. Behav. Res., vol. 24, no. 2, pp. 521-537, 2018, doi: 10.1108/IJEBR-06-2017-0184.

[9] R. L. Priem and J. E. Butler, "Is The Resource-Based View a Useful Perspective for Strategic IS THE RESOURCE-BASED " VIEW " A USEFUL PERSPECTIVE FOR STRATEGIC MANAGEMENT," no.
January, 2001, doi: 10.2307/259392.

[10] R. M. Grant, "The Resource-Based Theory of Competitive Advantage: Implications for StrategyFormulation," Calif. Manage. Rev., vol. 33, no. 3, pp. 114-134, 1991.

[11] N. P. Mishra et al., "Global impacts of preand post-COVID-19 pandemic: Focus on socio-economic consequences," Sensors Int., vol. 1, no. July, p. 100042, 2020, doi: 10.1016/j.sintl.2020.100042.

[12] S. Novika, "Bedanya Dampak Pandemi Corona ke UMKM dengan Krisis 1998," detikFinance, 2020. https://finance.detik.com/berita-ekonomibisnis/d-5101911/bedanya-dampakpandemi-corona-ke-umkm-dengan-krisis1998 (accessed Aug. 31, 2020).

[13] A. K. Pakpahan, "Covid-19 Dan Implikasi Bagi Usaha Mikro, Kecil, Dan Menengah," J. Ilm. Hub. Int., vol. 0, no. 0, pp. 59-64, 2020, doi: 10.26593/jihi.v0i0.3870.59-64.

[14] S. Reed, J. M. Gonzalez, and F. R. Johnson, "Willingness to Accept Trade-Offs Among COVID-19 Cases, Social-Distancing Restrictions, and Economic Impact: A Nationwide US Study," Value Heal., vol. 23, no. 11, pp. 1438-1443, 2020, doi: 10.1016/j.jval.2020.07.003.

[15] R. Mudassir, "Dampak Covid-19 ke UKM, 16 Persen Pelaku Usaha Pangkas Karyawan," Ekonomi Bisnis, 2020. https://ekonomi.bisnis.com/read/20200722 /9/1269901/dampak-covid-19-ke-ukm-16persen-pelaku-usaha-pangkas-karyawan (accessed Aug. 31, 2020).

[16] P. Madhani, "Resource Based View (RBV) of Competitive Advantage: An Overview," ... BASED VIEW CONCEPTS Pract. Pankaj ..., no. March 2010, 2010, [Online]. Available:

http://papers.ssrn.com/sol3/papers.cfm?abs tract_id=1578704.

[17] D. Collis and C. A. Montgomery, "Competing on Resources: Strategy in the 1990s," Harvad Business Review, 1995. https://hbr.org/1995/07/competing-onresources-strategy-in-the-1990s (accessed Sep. 18, 2020).

[18] J. Barney, "Firm Resources and Sustained Competitive Advantage," J. Manage., vol. 17, pp. 99-120, 1991.

[19] D. E. Nugraheny, "Pemerintah: PSBB Diberlakukan di Daerah Pusat Penularan Covid-19," Kompas.com, 2020. 
https://nasional.kompas.com/read/2020/04/ 15/09375511/pemerintah-psbb-

diberlakukan-di-daerah-pusat-penularancovid-19? page=all (accessed Oct. 03, 2020).

[20] D. Piovani et al., "Effect of early application of social distancing interventions on Covid-19 mortality over the first pandemic wave: an analysis of longitudinal data from 37 countries," J. Infect. no. $\quad \mathrm{xxxx}, \quad 2020$, doi: 10.1016/j.jinf.2020.11.033.

[21] W. A. N. G. Qingbin et al., "Impacts of the COVID-19 pandemic on the dairy industry: Lessons from China and the United States and policy implications," J. Integr. Agric., vol. 19, no. 12 , pp. 2903-2915, 2020, doi: 10.1016/S2095-3119(20)63443-8.

[22] T. H. Oum and K. Wang, "Socially optimal lockdown and travel restrictions for fighting communicable virus including COVID-19," Transp. Policy, vol. 96, no. June, pp. 94-100, 2020, doi: 10.1016/j.tranpol.2020.07.003.

[23] V. Grech and P. Grech, "COVID-19: Combined supply-side and demand-side shocks, so lift restrictions (carefully) lest GPD declines ultimately kill more than COVID-19," Early Hum. Dev., no. xxxx, 2020 , doi:

10.1016/j.earlhumdev.2020.105209. 